\title{
Figures on the Threshold: Refugees and the Politics of Hospitality, 1930-1951 ${ }^{1}$
}

\begin{abstract}
If, as Peter Gatrell has suggested, the figure of the refugee was, in many ways, defined and even constructed during the twentieth century, then the Second World War was a crucial period in this process (Gatrell, 2013). This article looks at three representations of refugee figures from this period, Graham Greene's novel The Name of Action (1930), Rebecca West's short story 'Around Us the Wail of Sirens' (1941) and Storm Jameson's novel The Black Laurel (1947), evaluating them in light of recent scholarship around hospitality and asylum to suggest that these refugee characters subvert the norms and customs of British hospitality. It argues that in these three texts, refugees act as 'threshold figures', exposing the realities of war and the inadequacy of British social processes to contain them. In doing so, they point toward a different way of representing the refugee as an active agent, rather than a passive recipient in both political processes and social interactions.
\end{abstract}

Keywords: refugees, hospitality, guests, Second World War, domestic spaces

During the Second World War, just as they become more visible in public life, refugees become more visible in fictional representations. Politically and socially, the refugee is being defined and understood during this period, ahead of having his or her legal position consolidated through the UN Convention Relating to the Status of Refugees signed in 1951. This definition would go on to influence the ways in which these figures were seen and understood in public and private life from that moment on. Just like these international laws, the social processes around helping or offering food, shelter or friendship to refugee figures, stem from traditional understandings of hospitality, of the relations between guest and host. Taking three examples from before, during and just after the war - Graham Greene's novel The Name of Action (1930), Rebecca West's short story ‘Around Us the Wail of Sirens' (1941) and Storm Jameson's novel The Black Laurel (1947) - I look at the ways in which these three writers represent the interactions between refugee and citizen, guest and host, within the domestic-social space of the British home. Examining this alongside recent scholarship around refugees and asylum, I 
suggest that these texts allow their refugee characters to subvert or circumvent traditional guesthost or refugee-host relations. These representations offer, as I will show, a more even footing for the exchange of information and ideas which placed refugees in a position of power and responsibility, far removed from what Peter Gatrell describes as the "passive and "traumatized" object of intervention' created by the political and legal discourses which evolved during the latter half of the twentieth century. ${ }^{2}$ I suggest that the encounters which take place within these fictional settings offer important insights into our own prejudices and suppositions about the nature of the refugee figure during this period.

It is the domestic settings, from parties to small gatherings, within the British home which provide a microcosm for the interactions between the refugee and the British state at this time. Hospitality operates at several levels, that of the state and the nation, inflected by International law such as that established by the League of Nations during the interwar period, by national laws and policies, and at a more personal and domestic level. On a smaller scale, and with British hosts and private homes symbolising the nation-state, these domestic spaces can be seen to enact not only the relations that these British writers may have had with refugees arriving in Britain at this time, but also the wider duties and responsibilities held by host and guest at a national or even an international level. All three of these writers were involved at a national level with state hospitality and asylum laws - Jameson as President of English PEN worked with the government to establish the needs and rights of refugee and exiled writers, West supported PEN's efforts, chairing committees, fundraising and accommodating refugees in her own home, and Greene came into contact with refugees through his post at the Ministry of Information. ${ }^{3}$ As such their fictional depictions of refugees serve to highlight not only their own real-life experiences with these figures, but also to gesture toward their own political and humanitarian convictions about Britain's role in the ongoing refugee crisis in Europe during this period. This is not to say that the comparison between individual hospitality and the codes of national or international law are interchangeable, but rather that, by adopting these domestic settings, authors are able to comment on one in order to cast light on the other, and vice versa. 
In these spaces, the intimacy of the home comes together with the unknowable nature of the foreign, representing a point of trauma and abjection but also of familiarity and domestic comfort. The home becomes a place in which the problematic politics of wartime hospitality are enacted, informed as they are by expectations on both sides and by generations of social and cultural convention. It becomes a battleground in and of itself, wherein the war, here embodied by the refugee, is permitted to enter the room, but only under certain circumstances and conditions. This article works through the disruptions and interruptions which the predicament of refugee figures pose to the niceties of social relations in these fictional domestic spaces. I argue that these three texts can be seen to examine prevalent attitudes to these figures, highlighting some of the prejudices and preconceptions which inform interactions between guest and host, refugee and citizen. Of course, it is impossible to ignore the fact that, especially in the texts I examine here, the refugee or exile can be seen to operate solely through the eyes of his or her hosts, potentially robbing them of their agency, their attempt to become subjects confined within the words of the privileged author, their textual host. However, I would argue that these three fictional settings interrupt guest-host relations in a way that is empowering for their refugee characters and which gestures to each author's own sense of the refugee as inherently valuable. I define these threshold figures as those in search of safety and yet reminiscent of all of the dangers of the war, who inhabit the domestic but bring with them the horror of the war, who are both simultaneously present in the domestic space and trapped in the actions of their past. Acting as a bridge between the war and the relative safety of Britain, these threshold figures serve as disruptions to the relative safety of the British homefront. Their disruption is a necessary one, their presence a crucial reminder of the human cost of the war. In all three cases, they are truth-givers, reminders that the realities of war cannot be glossed over, that the British occupy an incredibly privileged position as onlookers from a faraway island, and that the social niceties of peacetime cannot be applied to these wartime refugee-host interactions.

Of course, the term refugee is highly complex, particularly during the interwar and Second World War period. Hannah Arendt writes in We Refugees (1943) that, during this 
period, refugees became 'those of us who had been so unfortunate as to arrive in a new country without means and have to be helped by refugee committees'. ${ }^{4}$ In fact, as Claudena Skran explains in her exhaustive study of refugee law in the period, the 1933 and 1938 conventions established by the League of Nations describe refugees largely in terms of their specific country of origin, and establish relatively few concrete requirements in order to attain refugee status. They contain only the 'proviso that refugees are people who are outside their home country, lack the diplomatic protection of their home governments, and have not yet acquired another nationality. ${ }^{5}$ Kurtz, in Greene's story, has left his home country of Trier (this fictionalised Trier is a country and not a city) because of his political beliefs and threats from the country's military dictator; West's Rachel escapes Austria and a number of nations on the continent, fleeing the onward march of fascism, and Giermyski, in Jameson's novel, has left his country of Poland to escape the Nazi invasion. In the legal parlance of the time therefore, all three of these characters would qualify as refugees as each exists 'outside their home country', without 'the diplomatic protection of their home governments' and without 'another nationality'. These two early conventions, guaranteeing the rights and reception of refugees also make, as Skran explains, "no mention of the reasons for flight beyond the vague exclusion of persons who leave "for reasons of purely personal convenience" contained in the 1938 Conventions. ${ }^{6}$ As such, for the purpose of this study, all of the above-mentioned characters will be understood chiefly as refugees, in accordance with the legal guidance of the time, which we can presume informed the understanding and approach of their authors. ${ }^{7}$

Gatrell suggests that a real history of 'refugeedom', a term which he uses to refer to the overall processes that govern both the lived experience of refugees and the categories and legal requirements which define them, must incorporate 'a social and cultural history of refugees within shifting systems of power', and must 'be done in a way that does not see power flowing in one direction'. ${ }^{8}$ This article attempts to do just that, to look for the ways in which it is not only the British author who exerts power over the refugee figures they choose to represent, but also the "host" characters within the stories themselves, and to assess the ways in which these refugee figures can be seen to assert their own power within the text. In doing so, it argues that 
the threshold figures represented by Greene, West and Jameson enact a disruption of these power dynamics and gesture toward a way of reading and understanding the refugee not as the passive recipient of the hospitality overseen by the host and even the state itself, but also as someone who is contributing to, challenging and interrupting these norms in a way that is both valuable and positive. These texts might then suggest a different way of reading and thinking about the refugee which interrupts prevalent cultural narratives of the refugee that arose through the crises of the twentieth century and which were formalised through the legal and political processes which framed the founding the Office of the United Nations High Commissioner for

Refugees in 1951. These textual representations can be seen themselves to challenge a mainstream historical discourse increasingly inclined to view and represent refugees as passive recipients rather than as active agents in social and cultural processes. I suggest that they provide, not only a contrast to later constructions of the refugee, but also gesture toward a more complex and nuanced response to the refugee before he/she became so entrenched within international legal, political and cultural frameworks.

\section{The Figure on the Threshold}

Speaking more broadly of the outsider in history, in Gender and the Politics of History, Joan Scott asks 'how are those who cross thresholds received? If they belong to a group different from the one already "inside", what are the terms of their incorporation? How do these new arrivals understand their relationship to the place they have entered? ${ }^{9}$ How, indeed, are those figures who cross thresholds received and what are the politics of their incorporation? Current scholarship on hospitality is particularly engaged with the politics of welcoming and accommodating refugees, often framing twenty-first-century public debates around asylum within the context of social practices of hospitality both in a domestic and an international context. ${ }^{10}$ The political philosophy which governs many of these practices has its roots in some of the earliest philosophies of nation and statecraft: In 'To Perpetual Peace' (1789), Immanuel Kant asserts that 'Hospitality means the right of a stranger not to be treated as an enemy when he arrives in the land of another. ${ }^{11}$ For Kant, peace could only be achieved when a sense of 
world citizenship prevented man from viewing all foreign visitors as enemies. Yet, as Jacques Derrida writes much later, the exchange between host and guest is inherently violent because, in extending and accepting hospitality, both hôtes (host and guest) place certain conditions upon each other. For Derrida, hosting is always infused with the violence of control because the guest must:

ask for hospitality in a language which by definition is not his own, the one imposed on him by the master of the house, the host, the King, the lord, the authorities, the nation, the state, the father etc. This personage imposes on him translation into their own language and that's the first act of violence. ${ }^{12}$

This linguistic conformity is just the beginning of the concessions which the guest must make when entering a strange home or land. This conformity forms part of what Sara Ahmed calls an 'economy of hospitality' with their host, an interaction mired in the politics of exchange and expectation. ${ }^{13}$ Both guest and host must navigate a complex power dynamic, with expectations in terms of behaviour on both sides. This exchange is loaded with duties and responsibilities, as I go on to discuss, and inflects the behaviour of guests and hosts within these texts, as microcosm for both home and nation. For the refugee, these modalities of violence are still present, particularly in terms of the expectations placed upon him/her by the host. However, the status accorded to refugees within all three of these texts allows for a challenge and an interruption to these processes.

The very presence of the refugee represents not simply a challenge to these social norms, but rather a disruption which demands attention and elicits political and social change both within and without the space of the home. As I outline above, in these texts refugees can be seen to represent threshold figures, voices from the war who occupy the space of the home they enter, but who seem always tied to the war and its realities. They occupy simultaneously the space of the past (the war they have come from, the country they have left), the present (their adopted country, their adopted home), and the future (their plans to return home, their hopes for rebuilding their country). Storm Jameson herself describes the position of the refugee in her autobiography, writing that: 
the difference between French exiles and others was deep. When a German came into the room, and especially if he were a Jew, he brought with him part of the blackness of Europe, a sense that he had at his back not a country that he had for the time being lost but a gulf he would never re-cross: the Poles had their habit of exile, which almost took the place of the country they could not lose: the cautious, watchful, tough-fibred Czechs knew or thought they knew exactly how they would tidy the place up when they went back. $^{14}$

Jameson's evocative language depicts not only her own national preferences and preoccupations (she idealised Czechoslovakia throughout this period), but also a sense of the complexity of each refugee's experiences of exile and its effects. For Jameson, the position of refugees and exile is interchangeable, both being outside their country of origin and without its protections. For her, each refugee represents a figure on the threshold both of time and of space, tied equally to the place they have come from and their new location. These refugees are trapped in what Lyndsey Stonebridge, citing André Green, refers to as 'the borderline', a place which is ' $[\mathrm{n}]$ either this nor that, existing neither here nor there'. ${ }^{15}$ They represent both war and peace, Europe and England, past and present. This is even more evident in the domestic space of the home, where each represents a point of rupture, bringing the war into the safety of the domestic space, and demanding an engagement with the political processes outside.

Occupying this threshold or 'borderline space', the refugee figure can arouse a sense of danger and an excitement, expressed by the extract from Jameson's autobiography. This is a disruption that is inspired in part by the politics of difference, the otherness of the refugee figure. During World War Two, these 'neighbours' from Europe represented points of exoticism and even of inspiration. In the British homes depicted, this difference does not raise the heckles of the British hosts- even if their ignorance of English customs might - but rather piques their interest. As Sara Ahmed writes in Strange Encounters (2000), Derrida's discussion of welcoming the stranger and the violence of hospitality 'conceals how the very act of welcoming already assimilates others into an economy of difference'. ${ }^{16}$ This difference acts, in the circumstances of these British hosts and refugees, as a sort of currency. During the war, the 
presence of the other can be seen to offer a point of comparison for British hosts and even their other (British) guests, perhaps a relief that they too have not faced the dangers of the continent or perhaps a feeling of inadequacy that they may not pass such a test of their ideological or intellectual mettle: British experience of the war, of the Blitz and of the home front, was very different to that of European who had faced invasion and occupation and seen fighting first hand. This difference of experience offers a point of attraction for the host, representing a curio or object of interest. Within this 'economy' of difference, the refugee must fulfil expectations, performing the role of the freedom fighter, the revolutionary or the traumatised subject. In this context, the refugees represented in these three narratives can be seen to embody, not victims of the violent politics of assimilation, but figures of curiosity and excitement encouraging intellectual exchange and empathy. The attraction of refugees for their British hosts is symbolised by this difference and by their status on the threshold between the war on the continent and the relative safety of Britain, between the European and the British, between home and abroad.

Ahmed's 'economy of difference' is a just description of the rules and duties of hospitality, but its requirement for difference rather than assimilation does not change the power dynamics operating between guest and host within this context, the sense of exchange and expectation. Whilst in the British home, the balance of power can still be skewed toward the host, forcing the refugee, as threshold figure, to demonstrate his or her gratitude through a sense of duty or politeness. However, in the three fictional accounts I examine here, these threshold figures come to exert a great deal of influence, their allure as guests tied to their difference and their experience, which in these settings gives them the power to speak out and their authenticity as truth-givers. As Gatrell describes, refugees are often depicted both legislatively and culturally as 'corks bobbing along on the surface of an unstoppable wave of displacement' where 'speechlessness and passivity have become the norm. ${ }^{17}$ However, I would argue that the agency attributed to the refugee figures within these narratives interrupts this dynamic: These refugees are included precisely for the candidness of their accounts of war, their reiteration of their experiences guarantee them both a voice and a currency within the 'economy of 
hospitality' and even offer them the opportunity to disrupt some of the expectations of their hosts, often to explosive effect. Through the establishment of this agency, these three authors Greene, West and Jameson - offer important critiques of the ways in which refugees are traditionally represented and understood.

\section{The Writer and the Politics of Welcome}

During the 1930s, as countries across Europe fell to fascism and writers and thinkers faced persecution in Europe, the British home - particularly gatherings or parties in private homes came to be used as spaces for speaking out and challenging the censorship and repression of the public sphere. In the three texts I analyse here, influential British writers represent these domestic spaces, offering fictional interactions between refugees and their British hosts which interrogate relations between refugee and nation, guest and host. I argue that, in each of these texts, the refugee brings the war - through their experiences, their stories and their very presence - into the room. Greene's The Name of Action - a little-known novel, later repudiated by the author - represents the author's own perception of the importance of writing and literature as a revolutionary force during this period. In the book, English hostess Mrs Meadmore's party becomes a meeting place in which Oliver Chant, a wealthy Londoner, meets Kurtz, a foreign revolutionary. Kurtz is something of a novelty at the party, providing a point of interest for the assembled guests based around his very foreignness, his exoticism and his status as a refugee. In return for exemplifying these qualities and pandering to the 'economy of difference', Kurtz has an avid audience for the duration of the party, and, if he speaks well, some influential supporters. However, his influence moves beyond mere support and he convinces one party guest to return to his home country to deliver a message for him. Chant, the guest in question, is keen to show the refugee his willingness to offer help and his empathy, and to show that the British are also prepared to risk their lives to defend shared values. His decision is a manifestation of both national and masculine pride - he wishes to show that he is able to face the danger once faced by his guest. This is particularly welcome for Chant, one of the postFirst World War generation, yet to have their war and still in the shadow of the bravery and 
sacrifice of those who fought in Europe in 1914-18. Moreover, Chant's reaction typifies the presumptions of hospitality, showing a desire to continue to provide help and support alongside the necessity of maintaining a position of superiority, in this case by completing a mission which the refugee himself cannot attempt. Chant and Kurtz's relationship is, from the beginning, mired in the power dynamics of guest and host.

Kurtz asks Chant to return to his home country of Trier, named suggestively after a city in Germany, to deliver a message to the radical poet Joseph Kapper. In Trier, Kapper uses his poetry to promote freedom, democracy and justice in order to undermine the country's totalitarian government, and is engaged in revolutionary struggle along with a group of other men. Kurtz explains to Chant that 'a country can be made by its literature, made, I mean with a separate individuality. ${ }^{18}$ Chant is captivated by Kurtz as a voice of authenticity, one who has experienced the realities of the war close at hand, and is keen to experience this for himself. He is also persuaded by Kurtz's idealistic view of literature and his belief that Kapper's work represents all that is worth saving in Europe. For Chant, the struggle in Trier comes to epitomise artistic and intellectual freedom. This is enforced by Kurtz's name, implying perhaps that, like the character in Conrad's Heart of Darkness (1899), he is the man who lives among the uncivilised natives, in this case the uncivilised natives of Britain, a place devoid of Europe's superior culture. Chant's action then might become a desire to prove his countrymen civilised, cultured and the value they place on the literary as equal to that placed on it by Kurtz and his countrymen. His interaction with Kurtz at Mrs Meadmore's party marks not only an interaction with the war, but with European cultural life, and gestures toward another element of the allure of the threshold figure as purveyor of this culture. His taking part in action in Trier shows a British desire to be seen as integral not only to the war, but to European cultural life.

Chant's actions in Trier do much to support this reading. Once in Trier, Chant delivers his message but finds himself drawn into the world of the revolution, aided by his falling in love with the dictator's wife. Kapper explains, 'I write a poem one night, it is printed here next morning and during the night our agents fix it on every hoarding in Trier; it is pasted on the windows of the Palace itself; a copy is on every table in every restaurant. ${ }^{19}$ Chant becomes 
involved in this operation, helping to undermine the power of the government and encourage the people to think beyond the repressive systems of fascist rule. Chant's involvement leads eventually to the successful overthrow of the government, when he kills Trier's dictator. Without the chance meeting between a revolutionary and exile, and a privileged, literaryminded Londoner, the revolution in Trier would not have taken place. Kurtz represents not only a threshold figure, simultaneously between the war and the safety of Mrs Meadmore's British home, but also a gateway, allowing the host to experience the authentic thrills of wartime engagement. His presence within Mrs Meadmore's party affordfs him to use the politics of hospitality to promote his cause, to tell his story and, eventually, to succeed in his aim of overthrowing Trier's dictator. Through this exchange, Chant becomes a guest in Kurtz's country, placing himself on the frontline to fulfil not the duties of host but the duties, as he sees it, of all free men and women. He himself comes to occupy the threshold space in reverse, bringing his privilege as a Briton to bear on events in Trier and using it to gain the trust of its dictator. This privilege, as well as his manipulation of the rules of hospitality particularly whilst in the dictator's home see him, enact the ultimate betrayal: killing his host and fleeing with his wife. In Greene's novel, the domestic space offers a crucial meeting space for ordinary citizens and threshold figures, wherein the politics of hospitality can be manipulated and even subverted, where the duties of guest and host are in flux.

As we see in the case of Chant, the presence of these threshold figures offers a point of inspiration, bringing first-hand accounts of war and exile and, perhaps most crucially, a sense of authenticity to ordinary British characters' understanding of the war in Europe. This authenticity is unaffected and even enhanced by his status as a political refugee: Kurtz is an example of the real struggle for intellectual and political freedom taking place elsewhere in Europe. The presence of Kurtz also offers the opportunity to join the fight, as Chant does, and to feel informed and justified in doing so. As Kate McLoughlin writes, this sense of authenticity is crucial to any accounts of the of the war: 'those who have experienced war carry its news despite themselves, inescapably and for life: de facto war reporters, living bulletins. ${ }^{, 20}$ The authenticity of the accounts of these threshold figures comes precisely from being in close 
proximity to events as they unfold. In the case of refugees, their authority stems from their proximity to the conflict, and to the war in Europe. They bring crucial dispatches from the front lines because even if they were not able to witness them themselves, they were still far closer to the action than their hosts in Britain. These threshold figures, then, also offer a sense of an authentic experience of the war, bringing their hosts closer to the conflict, if not physically, as in Chant's case, then through their stories and reports.

\section{The Threshold Figure as Truth-Teller}

In offering these accounts of the war, refugee guests in these selected texts function as authentic voices from the front line of the conflict but also as imparters of truth. Their allure for their hosts is linked to this truth and, as truth-tellers they can be exempted, or at least indulged in deviating from the traditional norms of hospitality. They can be seen, not only though their interactions within domestic spaces but also through their refusal to conform to traditional norms of gratitude or politeness, to offer a challenge or a renegotiation of the relationship between the refugee guest and his or her privileged host. For the writers representing these threshold refugee figures - Greene, West and Jameson - they offer a similar opportunity for truth-telling, this time a way of disrupting the norms of British hospitality by themselves giving voice to challenges to established customs and values. Their texts offer space for some renegotiation of the relationship between guest and host, citizen and refugee, in order to explore the contradictions and inadequacies of this relationship. While Greene offers a blurring of the lines governing the host-guest relationship, both West and Jameson offer ways of challenging the hosts expectations of refugee guests. In both narratives, the threshold figures allow the war to enter the British drawing room through their stories and their experiences but also serve to draw attention to the problematic power dynamics between guest and host and the expectations placed on both sides. These figures on the threshold represent the potentially transformative power of refugee encounters, marking out the problematic nature of the power dynamics between guest and host. As well as representing authoritative accounts of the war, these fictional refugee figures give Jameson and West the opportunity to offer authoritative critiques 
of the norms of hospitality itself, and, through this, the national and international systems which controlled asylum.

In West's short story of 1941 'Around us the Wail of Sirens', Rachel, a young Austrian refugee is taken into a British home. Rachel's behaviour, and the responses of her hosts and their guests, does much to illustrate the problematic relationship between refugee guest and host. Rachel also represents a threshold figure, bringing the war into the comfortable London home in which she stays, and often not in the ways that her hosts had anticipated. Rather than being grateful or traumatised, Rachel is angry:

I have to leave Vienna for Prague, and then I have to leave Prague for Amsterdam, and then I have to leave Amsterdam for London, and they say that here I will never have to move because the defences are so good. But I never believed them. Still, it is very hard luck on me. ${ }^{21}$

Rachel is mindful that coming to Britain was not her choice, not a fanciful excursion to enjoy the country, but rather a traumatic journey compelled by the breakdown of her own home nation. Her displacement, despite her use of the word 'travel', is an enforced relocation, a necessary exile. The displeasure of her hosts at her failure to acknowledge her good fortune can be critiqued as an early judgement on British attitudes to refugees. Here, the refugee's own experiences of wartime displacement are still secondary to British modes and demands of hospitality because Rachel is expected to behave in the way her hosts demand, to tell the stories that they want to hear. In illustrating Rachel as an ungrateful guest, West hits upon the fundamental power dynamics between refugee figures and their British hosts, shedding light on the unbalanced power relations between them.

As the story goes on, Rachel continues to lament her surroundings and begins to compare her home country most unfavourably to her host country: 'You two have travelled. You know what wonderful food we have in Austria. You can guess what torture your monstrous diet is to us Austrians. ${ }^{22}$ Although Rachel defers to her host by speaking English, the primary element of the 'violence' Derrida describes, she does not defer in any other way. Instead, she offers a scathing critique not only of her host nation but also of her hostess's cooking! In so 
doing, Rachel acts in direct contravention of what Sara Ahmed has called the 'happiness duty', to tell a positive story about the good of her arrival, to show gratitude through flattery. ${ }^{23}$ As Ahmed observes, 'gratitude and happiness to be in their new home is a duty incumbent upon the migrant, who must acknowledge continually his or her good fortune at their new circumstances. ${ }^{24}$ For her, ' $[\mathrm{t}]$ he happiness duty for migrants means telling a certain story about your arrival as good, or the good of your arrival. The happiness duty is a positive duty to speak of what is good but can also be thought of as a negative duty not to speak of what is not good, not to speak from or out of unhappiness. ${ }^{25}$ All Rachel can do is to voice her anger at the failings of her hosts and her disillusionment at finding herself in what she deems an inferior country. Far from fulfilling any obligation to happiness or gratitude, her behaviour is displeasing to her hosts. This is a direct subversion of the 'economy of hospitality'. Rachel is in receipt of hospitality - food and shelter - but she is not fulfilling her side of the bargain in offering gratitude, flattery, and even entertainment to reward her hosts for their generosity. Quite the reverse: her complaints make her hosts feel unhappy and they insult their generosity.

Yet while, as readers, we may feel slightly shocked at Rachel's rage, our sympathy does not lie with her hosts who often appear superior, unfeeling or even unkind. Instead Rachel's outbursts force us to question the motives of those taking in refugees and feeling offended at their homesickness and, in turn, to question a culture of hospitality that places social nicety ahead of empathy. Perhaps Rachel is a manifestation of Ahmed's 'melancholy migrant', in that she is a happiness-giver who interrupts and challenges this expectation by giving voice to negative feelings. ${ }^{26}$ Certainly Rachel's negative feelings force a reassessment of the principles which govern hospitality, particularly in relation to the refugee. Rachel's behaviour can be seen to undermine the refugee's 'happiness duty' and to make a mockery of the expectance of gratitude and reciprocity. Rachel's status as a refugee, entirely dependent on the hospitality of her British hosts and that of the British state itself, make her an unsympathetic critic. She is shown to be an unwilling guest, or an unwilling subscriber to the rules of hospitality now placed upon her. From this perspective, her status as refugee allows her to critique these rules. West's story depicts the uneven power relations, the precarity of Rachel's position and her dependence, 
critiquing the structures of traditional hospitality and asylum by giving voice to the unhappy refugee, a sister of Ahmed's 'melancholy migrant'. ${ }^{27}$

Further for West's readers and even the author herself, the figure of Rachel also acts as a crucible for negative feelings. Rachel as a character allowed West herself to think through some of her own issues with the countless Yugoslavian refugees who took up residence at her country home, Ibstone, often for months at a time. ${ }^{28}$ The story can be interpreted as a way for West of working through her own negative feelings toward her refugee guests. Further, Rachel allows readers, both in the US, where the story was published in the Saturday Evening Post, and the UK, to work through negative feelings about the arrival of refugees and exiles from Europe and to process their own feelings of indignation or displeasure at refugees' behaviour. Rachel takes up her place as a threshold figure between war and the comparative peace of England to allow those on the Home Front, on either side of the Atlantic, to feel closer to, and more involved with, the conflict but also to feel angry or displeased with their guests and with the behaviour. As well as demonstrating the complexities of being an ill-mannered refugee, the story also explores the actions of bad hosts, who find a new home for Rachel and force her out, thus neglecting their own duty to care for their guests. The story allows both readers and West herself to embrace their own negative experiences of war, and to re-think their own attitudes to and expectations of refugees and of themselves.

Even after the war, refugee guests, as Jameson's text illustrates, still bring with them unwanted and uncomfortable truths, based on their first-hand experiences beyond the walls of the home and the shores of Britain. Further, they offer a point from which to look back at what Britain and British hospitality offered the refugee, and at how the presence of refugees may have made a positive impact on British intellectual or social life. In The Black Laurel, one such threshold figure is unashamed to share his strong opinions with his hosts at society hostess Mrs Brett's intellectual gatherings in wartime London. Jameson's backwards glance to the war, two years after its end, shows a more considered response to the role of Britain as the recipient of Europe's refugees, and gestures toward its place within processes of reconciliation as part of a united Europe. As the guests enjoy Mrs Brett's hospitality, the aging art critic Cecil Cowley 
tells those assembled that 'somehow Europe must be saved. ${ }^{29}$ A young Pole, invited to the party, interjects 'with a contempt no less bitter for its air of gaiety, even joy', criticising Cowley's idealised view of Europe. ${ }^{30}$ He tells Cowley that, 'you English have the most comfortable room in [Europe], while we live in a hideously draughty ante-room. The coming and going in our room is terrible. ${ }^{31}$ Gierymski, a Polish refugee serving in the British army, asks how there can be any enduring connection between those existing under an apparently unending cycle of occupation, invasion and annexation and those in the 'most comfortable room', England, which has not experienced occupation in living memory. Insulting his English hosts for their safety and complacency, he tells those assembled that they can never understand what it really means to be part of continental Europe and to have one's country constantly under threat from one's neighbours. As a threshold figure, he makes clear his presence as a rupture within the domestic space, interrupting the peace and decorum of the space to draw attention to uncomfortable truths.

In criticising his hosts, Gierymski breaks with the conventions of hospitality, demonstrating their irrelevance in times of war to those who, faced with invasion, have cast aside all such niceties in their desire for justice. Through this he makes clear that, while the British may feel that they have sacrificed a great deal in taking in refugees and coming to the aid of their European allies, they still have not come to truly understand the European condition. His words chime with much of Jameson's fiction of the post-war period, which investigates the possibilities of forgiveness in Europe and often posits British characters as having little or no understanding of the repeated invasions and occupations endured by their European Allies. This is a harsh truth for those, such as Cowley and others at the party, who like to view themselves as cosmopolitan figures, enduring Europe's suffering along with it. That Giermyski would draw attention to this lack of awareness in his hosts, and would do so despite the help that they have offered him, indicates a bitterness between refugees in Britain and their hosts. Giermyski is like Rachel, an unhappy and unwilling entrant into the 'economy' of hospitality. For Jameson, there is a sense that the British do not and cannot empathise with the struggles of their guests and therefore are unable to offer the necessary help. 
Giermyski's words interrupt and challenge discourses around Britain's generosity during the war by gesturing toward the country's tremendous privilege as an island nation, and the obligations that come with it. Giermyski seems to suggest, to use the earlier metaphor, that Britain's large room should accommodate a number of those fleeing conflict elsewhere, that the country's generosity is a necessary response to this privilege. Here, it is, according to Giermyski, the British as hosts who are laden with responsibility and duty, not their refugee guests. His duty is to open their eyes to the suffering in Europe and to make his hosts understand their privileged position, and prevent them from idealising or romanticising that of others. He also offers an unpleasant perspective on the war for the British, giving voice to the idea that, however they may have helped or taken part in the conflict, they can and will never understand European identity from their position on the outskirts. He suggests that the European experience can only be understood by those who are subject to the constant 'comings and goings' of the continent. In 1947, this is particularly significant as Britain began to take a lead role in the formation of a united Europe. As Britain was keen to place itself centrally in these negotiations, Gierymski's words point to a desire to end British complacency and to make the case that, despite its hopes for a central role in a united Europe, Britain must now hand over to those inhabiting Europe's 'draughty ante-room[s]' ${ }^{32}$ After the war Jameson, herself a fervent pro-European, is keen for the British to be part of Europe, but also for it to acknowledge the perspectives of its neighbours who may have more at stake in a postwar plan for the Continent.

Gierymski's words are permitted because his contribution as a threshold figure at these social events reaches beyond the duty of happiness: the refugee's duty of authenticity and of reportage far exceeds social expectations. Jameson employs him as such, to call attention to Britain's assumptions about its role in the European conflict. In the context of the party, Gierymski is performing his function as a threshold figure in challenging the views of the establishment. Even after the war, the experiences of refugee figures such as Jameson's Giermyski, and the combination of insight and authenticity offered by these characters, still provides a crucial counter to dominant perspectives on the war. Just as Rachel allows West to challenge and critique the wartime economy of hospitality, so Giermyski allows Jameson to 
address Britain's postwar position in Europe, and to comment on what its future role in the continent should be. These threshold figures perform several important functions in each of these narratives, providing indispensable insights into both European experience of war and relationship with Britain, but also interrupting and challenging the politics and practices of asylum and hospitality.

\section{Conclusion}

The three stories examined here show how attitudes to refugees evolved before, during and after the war. Moving from the refugee character as an agent in the post-First World War generation's desire to prove themselves, to the refugee as a truth-teller offering the opportunity to encounter and process the war for Blitz-era Britain, and finally to the post-war truth-teller exposing the real politics at work in Europe, each text represents a character who shows the importance of threshold figures in highlighting refugee experience. These fictional encounters gesture toward an exchange between refugee figures and their hosts within domestic spaces that subverts the rules and traditions of hospitality. These encounters are not about an exchange of kindness and social nicety in wartime, but are often more aligned to an exchange of truths and a challenging of established power relations between host and guest. The instances of negative behaviour and of truth-telling in these narratives highlight the importance of the refugee's role in these settings, as the authentic voice of the war-demonstrating the importance of these figures as truth-givers . For Greene, West and Jameson, these threshold figures fulfil vital functions in each story, challenging preconceptions about refugees and offering British characters insight into not only the refugee experience but the European experience of war.

In this manner, these fictional represenatations denote a departure from more prevalent conceptions of the refugee: As Liisa Malkki has suggested, the refugee is most often constructed in political discourse as an 'unreliable informant', where the administrators charged with assessing refugees for international protection under the 1951 Convention often approach their

charges as inherently 'dishonest, prone to exaggeration, even crafty and untrustworthy. ${ }^{, 33}$ Thus the attribution of truth-telling qualities to refugees in these World War Two stories, and the 
agency with which these refugees are imbued, is in stark contrast to twenty-first-century perceptions of the refugee. Malkki herself attributes this disparity to the current international systems that assess refugees in order to ascertain whether or not they qualify for assistance. Whilst this particular argument lies beyond the scope of this paper, it does point to a useful and illuminating difference in the ways in which refugees were perceived during this earlier period and gestures perhaps toward the effects - as Malkki would argue - of later legislation and administration surrounding refugees on public perception and cultural representation of the refugee. For all that these fictional refugee figures can be seen as the beneficiaries of British hospitality, they are also shown to hold currency within the 'economies of hospitality' in which they operate - that of authenticity and truth-telling. This authenticity stems from the refugee's close experiences of conflict and its value from the insight which this might bring to the British host or his/her guests. On this understanding, each of these characters are active agents, not simply passive recipients of British or international hospitality and aid. Within each narrative each refugee makes a vital contribution to the gathering or the home, through telling the truth of their experiences and offering a new perspective on both hospitality and the war itself to their hosts. In depicting refugee characters in this way each of these authors hints at their own understanding of refugees, as complex and worthy subjects with a part to play in wider British political and cultural life.

\footnotetext{
${ }^{1}$ I would like to thank Dr Ruth Connolly for her thoughts and advice on this idea of 'threshold figures'.

${ }^{2}$ P. Gatrell, The Making of the Modern Refugee (Oxford, 2014), p. 8.

${ }^{3}$ Britain's policy toward refugees during this period was influenced by both what Claudena Skran has called the 'international regime' (1995: 5), international laws developed in the interwar years by the International Refugees Organisation (IRO), and domestic laws which
} 
indicated how much hospitality, accommodation and social welfare, the state might be willing to offer.

${ }^{4}$ H. Arendt, 'We Refugees'. In: M. Robinson (ed.) Altogether Elsewhere: Writers on Exile (London, 1994), pp. 110-119 (p. 110).

${ }^{5}$ C. Skran, Refugees: A Human Problem in A World of States (Oxford, 1995), p. 72.

${ }^{6}$ Skran, p. 72.

${ }^{7}$ Of course, following the 1951 Convention, it would be significantly more complex to read these characters as refugees. Gierymski and Kurtz would probably be better understood as exiles, but Rachel would remain a refugee, for all intents and purposes.

${ }^{8}$ P. Gatrell, 'Refugees - What's Wrong With History?', Journal of Refugee Studies, 30:2 (2017), 170-189.

9. Wallach Scott, ‘American Women Historians, 1884-1984'. In: J. Wallach Scott (ed.) Gender and the Politics of History (New York, 1999), pp. 178-98.

${ }^{10}$ See, for example: Derrida (2000); La Caze (2004); Darling (2009); Brun (2010);

${ }^{11}$ I. Kant, (1795) Perpetual Peace. (Minneapolis, [1795] 2000), p. 4.

${ }^{12}$ J. Derrida, Of Hospitality: Anne Duformantelle asks Derrida to Respond, Rachel Bowlby (trans.) (Stanford, CA, 2000), p. 15.

${ }^{13}$ S. Ahmed, Strange Encounters: Embodied Others in Postcoloniality (Abingdon, 2000), p. 151.

${ }^{14}$ S. Jameson, Journey From the North: Volume I (London, 1970), p. 103.

${ }^{15}$ L. Stonebridge, 'Statelessness and the poetry of the Borderline: André Green, W.H. Auden and Yousif M. Qasmiyeh', Textual Practice, 29:7 (2015), 1331-1354 (p. 1334).

${ }^{16}$ Ahmed, Strange Encounters, pp. 150-1.

${ }^{17}$ Gatrell, Modern Refugee, p. 9.

${ }^{18}$ G. Greene, The Name of Action (London, 1930), p. 10.

${ }^{19}$ Greene, p.41. 
${ }^{20} \mathrm{~K}$. McLoughlin, Authoring War: The Literary Representation of War from the Iliad to Iraq (Cambridge, 2011), pp. 23-24.

${ }^{21}$ R. West, 'Around Us the Wail of Sirens', Saturday Evening Post, 8 February 1941, pp. 27-29 (p. 28).

${ }^{22}$ West, p. 49.

${ }^{23}$ S. Ahmed, The Promise of Happiness (Durham, NC, 2010), p. 158.

${ }^{24}$ Ahmed, Happiness, p. 158.

${ }^{25}$ Ahmed, Happiness, p. 158.

${ }^{26}$ Ahmed, Strange Encounters, p. 49.

${ }^{27}$ Ahmed, Happiness, p. 158.

${ }^{28}$ C. Rollyson, Rebecca West: A Saga of the Century (London, 1995), p. 151.

${ }^{29}$ S. Jameson, The Black Laurel (Basingstoke, 1947), p. 123.

${ }^{30}$ Jameson, Black Laurel, p. 123.

${ }^{31}$ Jameson, Black Laurel, p. 123.

32 Jameson, Black Laurel, p. 123.

${ }^{33}$ L. Malkki, 'Speechless Emissaries: Refugees, Humanitarianism and Dehistoricisation', Cultural Anthropology, 2:3 (1996), 377-404 (p. 384). 